\title{
ALDH enzyme activity is regulated by Nodal and histamine in the A549 cell line
}

\author{
YANG JIANG ${ }^{1}$, HUI LI $^{2}$, YI WANG ${ }^{3}$, TIAN TIAN ${ }^{3}$, YAN HE $^{1}$, YINJI JIN ${ }^{1}$, CHANGSONG HAN $^{1}$, \\ XIAOMING JIN $^{1}$, FENGMIN ZHANG ${ }^{4}$ and EIICHI MORII ${ }^{3}$ \\ ${ }^{1}$ Department of Pathology, Harbin Medical University, Harbin, Heilongjiang 150081; ${ }^{2}$ Department of Gastroenterology, \\ The Second Affiliated Hospital of Harbin Medical University, Harbin, Heilongjiang 150086, P.R. China; \\ ${ }^{3}$ Department of Pathology, Osaka University Graduate School of Medicine, Suita, Osaka 565-0871, Japan; \\ ${ }^{4}$ Department of Microbiology, Harbin Medical University, Harbin, Heilongjiang 150081, P.R. China
}

Received December 25, 2015; Accepted June 27, 2017

DOI: $10.3892 / \mathrm{ol} .2017 .7057$

\begin{abstract}
The present study aimed to examine whether the enzyme activity of aldehyde dehydrogenase (ALDH) was regulated by Nodal and histamine in the human alveolar adenocarcinoma A549 cell line. The regulated enzyme activity of ALDH was analyzed by flow cytometry in the A549 cell line. ALDH1 and Nodal expression was investigated by immunohistochemistry in 28 cases of lung mixed adenocarcinoma. The enzyme activity of ALDH was upregulated by histamine and agonists of histamine $\mathrm{H} 1$ receptor (H1R) and histamine $\mathrm{H} 2$ receptor $(\mathrm{H} 2 \mathrm{R})$. ALDH activity was also downregulated by recombinant human Nodal and antagonists of H1R and H2R in the A549 cell line. In addition, expression of Nodal and ALDH1 were inversely correlated in lung mixed adenocarcinoma. ALDH enzyme activity was regulated by Nodal and histamine in lung adenocarcinoma.
\end{abstract}

\section{Introduction}

Lung cancer is a leading cause of cancer-associated mortality, and has an increased incidence and mortality compared with other cancers worldwide (1). Among the various histological subtypes of lung cancer, adenocarcinoma is the most common subtype in the majority of countries, accounting for approximately one-half of lung cancers (2). At present, numerous studies indicate that there is a particular subpopulation of

Correspondence to: Professor Fengmin Zhang, Department of Microbiology, Harbin Medical University, 157 Baojian Road, Harbin, Heilongjiang 150081, P.R. China

E-mail: fengminzhang@ems.hrbmu.edu.cn

Professor Eiichi Morii, Department of Pathology, Osaka University Graduate School of Medicine, 2-2 Yamada-Oka, Suita, Osaka 565-0871, Japan

E-mail: morii@molpath.med.osaka-u.ac.jp

Key words: aldehyde dehydrogenase, nodal, histamine, A549, lung mixed adenocarcinoma tumor cells responsible for the prosperity and metastasis of tumors, although these cells are rare. These cells are commonly termed cancer stem cells (CSCs) or cancer initiating cells. The possible presence of CSCs has now been shown in the majority of cancers (3). Characterized by the abilities of self-renewal, differentiation and tumorigenicity, CSCs are considered to be able to form tumors with high efficiency, and also re-build the tumor with the whole lineage of tumor cells (4). Although methods of identifying CSCs remain to be elucidated, it is known that CSCs express surface molecules, in addition to the identified functional characteristics of stem cells; identification methods include measuring the activity of aldehyde dehydrogenase (ALDH) by ALDEFLUOR assay. At present, ALDH has been well accepted as a reliable CSC marker (5). In addition to the role of identifying the CSCs, the family of ALDH enzymes, which consists of 19 isoforms that localize to the cytoplasm and mitochondria of the nucleus, also manifest the capability to oxidize endogenous and exogenous aldehydes to carboxylic acids (6). Thus, ALDH also has a protective role in the process of maintaining the homeostasis of cells, which may benefit the survival of cancer cells. However, ALDHs also perform other roles that include ester hydrolysis, acting as binding proteins for cholesterol and acting as antioxidants in the process of NADPH production (7). In general, the diverse characteristics of ALDH are associated with the stemness of CSCs.

Therefore, investigating the regulation of expression and enzyme activity of ALDH is extremely important. In the present study, the expression of ALDH1 and Nodal was assessed in 28 cases of lung mixed adenocarcinoma, and the enzyme activity of ALDH was also investigated in the lung adenocarcinoma A549 cell line treated with histamine, rhNodal and the agonists and antagonists of histamine $\mathrm{H} 1$ receptor (H1R) and $\mathrm{H} 2$ receptors by flow cytometric assay.

\section{Materials and methods}

Lung mixed adenocarcinoma samples. A total of 28 lung mixed adenocarcinoma tissue samples were obtained from the Pathology Department of Osaka University Affiliated Hospital (Suita, Japan). All cases were graded according to the 
2011 World Health Organization classification (8). The study was approved by the Osaka University Ethical Review Board (approval no. 15234). The requirement for patient consent was waived by the Ethical Review Board, due to the anonymized retrospective nature of the present study.

Cell culture. The A549 cell line was obtained from the Cell Repository of Osaka University and cultured at $37^{\circ} \mathrm{C}$ with $5 \% \mathrm{CO}_{2}$, high glucose Dulbecco's modified Eagle's medium (Wako Pure Chemical Industries, Ltd., Osaka, Japan), 10\% fetal calf serum (HyClone; GE Healthcare Life Sciences, Logan, UT, USA), $100 \mathrm{U} / \mathrm{ml}$ penicillin and $100 \mu \mathrm{g} / \mathrm{ml}$ streptomycin (Invitrogen; Thermo Fisher Scientific, Inc., Waltham, MA, USA).

Immunohistochemistry. Lung mixed adenocarcinoma tissues (28 samples) were fixed using $10 \%$ formalin for $72 \mathrm{~h}$ at room temperature, embedded in paraffin and then cut into $5 \mu \mathrm{m}$ sections and mounted onto slides. Subsequent to deparaffinization in xylene and rehydration in graded ethanol, slides were pretreated for antigen retrieval using citrate buffer (pH 6) under $120^{\circ} \mathrm{C}, 2,020 \mathrm{kPa}$ for $20 \mathrm{~min}$. Sections were incubated with Dako Real Peroxidase-Blocking solution, which contained $3 \%$ hydrogen peroxide, $15 \mathrm{mmol} / \mathrm{l} \mathrm{NaN} 3$ and Tween-20 (Agilent Technologies, Inc., Santa Clara, CA, USA) for $5 \mathrm{~min}$ at room temperature, and then washed three times with PBS containing $0.01 \%$ Tween (PBST) for $5 \mathrm{~min}$ each time. ALDH1 and Nodal were detected by incubating the slides with mouse anti-human ALDH1 monoclonal antibodies (cat. no. 611194; BD Biosciences, San Jose, CA, USA) and mouse anti-human Nodal monoclonal antibodies (cat. no. ab55676; Abcam, Tokyo, Japan) at a dilution of 1:200 at room temperature for $1 \mathrm{~h}$. Subsequent to washing, the slides were treated with horseradish peroxidase-conjugated rabbit anti mouse IgG (cat. no. 354, Medical \& Biological Laboratories Co., Ltd., Nagoya, Japan) for $30 \mathrm{~min}$ at room temperature. Subsequent to washing with PBST, the slides were incubated with Dako Detection Reagent Envision kit (Agilent Technologies, Inc.) for 5-15 sec at room temperature and were counterstained with hematoxylin for $1 \mathrm{~min}$, followed by dehydration and sealing.

Antibody binding was recognized as brown cytoplasmic staining by light microscope (magnification, x100; Fig. 1A). Each sample of lung mixed adenocarcinoma consisted of multiple subtypes, such as the lepidic, acinar, papillary, micropapillary and solid with mucin production subtypes. The percentage of ALDH1-positive tumor cells among each subtype, including lepidic, acinar, and papillary subtypes, was calculated. Similarly, the percentage of Nodal-positive tumor cells was calculated. In each subtype, the percentage of ALDH-positive and that of Nodal-positive cells were plotted (Fig. 1B). Based on the pots, the association between ALDH1 and Nodal could be measured using a nonparametric statistical method. $\mathrm{P}<0.05$ was considered to indicate a statistically significant difference.

Flow cytometry. In the present study, the living A549 cells were directly stained without fixation. Reagents used to treat A549 cells at $37^{\circ} \mathrm{C}$ included: Recombinant human Nodal (rhNodal; 100, 300 or $500 \mathrm{ng} / \mathrm{ml}$; duration, 2 h; cat. no. OLF0812051; R\&D Systems, Inc., Minneapolis, MN,
USA); histamine dihydrochloride $(10,100,500 \mu \mathrm{g} / \mathrm{ml}$; duration, 2,4,18 h; Sigma-Aldrich; Merck KGaA); and the agonists and antagonists of human histamine receptors H1R and H2R. The agonist of H1R [histamine trifluoromethyltoluididedimaleate (HTM); concentration, $100 \mu \mathrm{M}$; duration, $2 \mathrm{~h}$ ] agonist of $\mathrm{H} 2 \mathrm{R}$ [dimapritdihydrochloride (DIM); concentration, $100 \mu \mathrm{M}$; duration, $2 \mathrm{~h}$ ] and the antagonist of H2R [cimetidine (CIM); concentration, $100 \mu \mathrm{M}$; duration, $2 \mathrm{~h}$ ] were all purchased from Tocris Bioscience (Bristol, UK). The antagonist of H1R [pyrilamine maleate salt (PYR); concentration, $100 \mu \mathrm{M}$; duration, $2 \mathrm{~h}$ ] was purchased from Sigma-Aldrich (Merck KGaA).

A549 cells were plated onto a 6-well plate and were cultured for 2,4 or $18 \mathrm{~h}$ with the reagents $(10,100$ or $500 \mu \mathrm{g} / \mathrm{ml}$ histamine; 100,300 or $500 \mathrm{ng} / \mathrm{ml} \mathrm{rhNodal}, 100 \mu \mathrm{M}$ MHTM, $100 \mu \mathrm{M}$ DIM, $100 \mu \mathrm{M}$ PYR and $100 \mu \mathrm{M}$ CIM). Adherent A549 cells were then harvested with trypsin containing $0.25 \%$ EDTA (Gibco; Thermo Fisher Scientific, Inc.) at a concentration of $2 \times 10^{5}$ viable cells for each sample, and were applied in the detection of the enzymic activity of ALDH. The percentage of ALDH-positive A549 cells was used to reflect the ALDH activity (9) by using the ALDEFLUOR assay kit, which contained fluorescent substrate for ALDH, termed boron-dipyrromethene (BODIPY) aminoacetaldehyde, that consisted of an aminoacetaldehyde moiety bonded to the BODIPY fluorochrome (Stemcell Technologies, Inc., Vancouver, BC, Canada). The labeled cells were analyzed using a BD FACSCantoII (BD Biosciences) and analyzed using FACSDiva6.1.3 software (BD Biosciences). Each sample was measured three times.

Reverse transcription-polymerase chain reaction. Total RNA was extracted from A549 cells using a RNeasy Mini kit (Qiagen, Inc., Valencia, CA, USA) and converted into cDNA and amplified using a Super Script III RNase H-Reverse Transcriptase kit (cat. no. 1244390; Invitrogen; Thermo Fisher Scientific, Inc.). The resulting cDNA was amplified in a final volume of $25 \mu \mathrm{l}$ containing $2.5 \mathrm{pmol}$ of each primer and $12.5 \mu \mathrm{l}$ of PrimeSTAR MAX DNA polymerase (Takara Bio, Inc., Otsu, Japan). The amplification conditions were denaturation at $98^{\circ} \mathrm{C}$ for $10 \mathrm{sec}$ (5 min for the first cycle), annealing at $55^{\circ} \mathrm{C}$ for $5 \mathrm{sec}$, and extension at $72^{\circ} \mathrm{C}$ for $1 \mathrm{~min}$ for 40 cycles for the amplification of H1R, H2R and H4R. The amplification conditions of H3R were denaturation at $94^{\circ} \mathrm{C}$ for $30 \mathrm{sec}(5 \mathrm{~min}$ for the first cycle), annealing at $59^{\circ} \mathrm{C}$ for $30 \mathrm{sec}$, and extension at $72^{\circ} \mathrm{C}$ for $1 \mathrm{~min}$ ( $5 \mathrm{~min}$ for the last cycle) for 40 cycles. The amplification products (each $10 \mu \mathrm{l}$ ) were separated on $2 \%$ agarose and stained by ethidium bromide. The primers (Applied Biosystems; Thermo Fisher Scientific, Inc.) of H1R, H2R, H3R and H4R were used as below (10): H1R forward, 5'-CATTCTGGGGGCCTGGTT TCTCT-3' and reverse, 5'-CTTGGGGGTTTGGGATGG TGACT-3'; H2R forward, 5'-CCGGCTCCGCAACCT-3' and reverse, 5'-CTGATCCCGGGCGACCTTGA-3'; H3R forward, 5'-TCAGCTACGACCGCT TCCTGTCGGTCAC-3' and reverse, 5'-TTGAGTGAGCGCGGCCTCTCAGTGCCCC-3'; and H4R forward, 5'-GAATTGTCTGGCTGGATTAATTTG CTAATTTG-3' and reverse, 5'-AAGAATGATGTGATGGCA AGGATGTACC-3'.

Reverse transcription-quantitative polymerase chain reaction (RT-qPCR). RT-qPCR was performed using $200 \mathrm{ng}$ cDNA 
$\mathbf{A}$
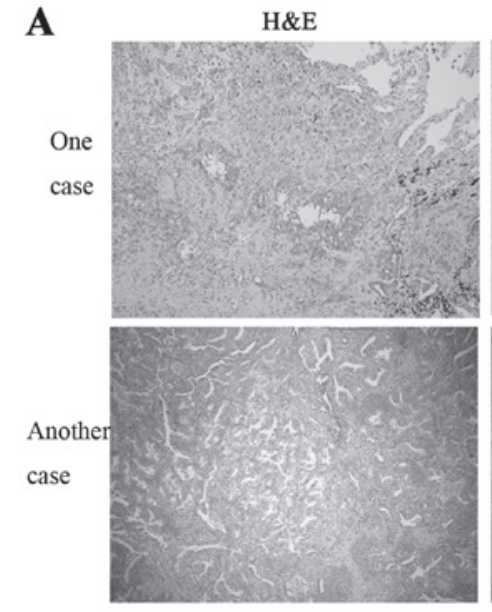

B

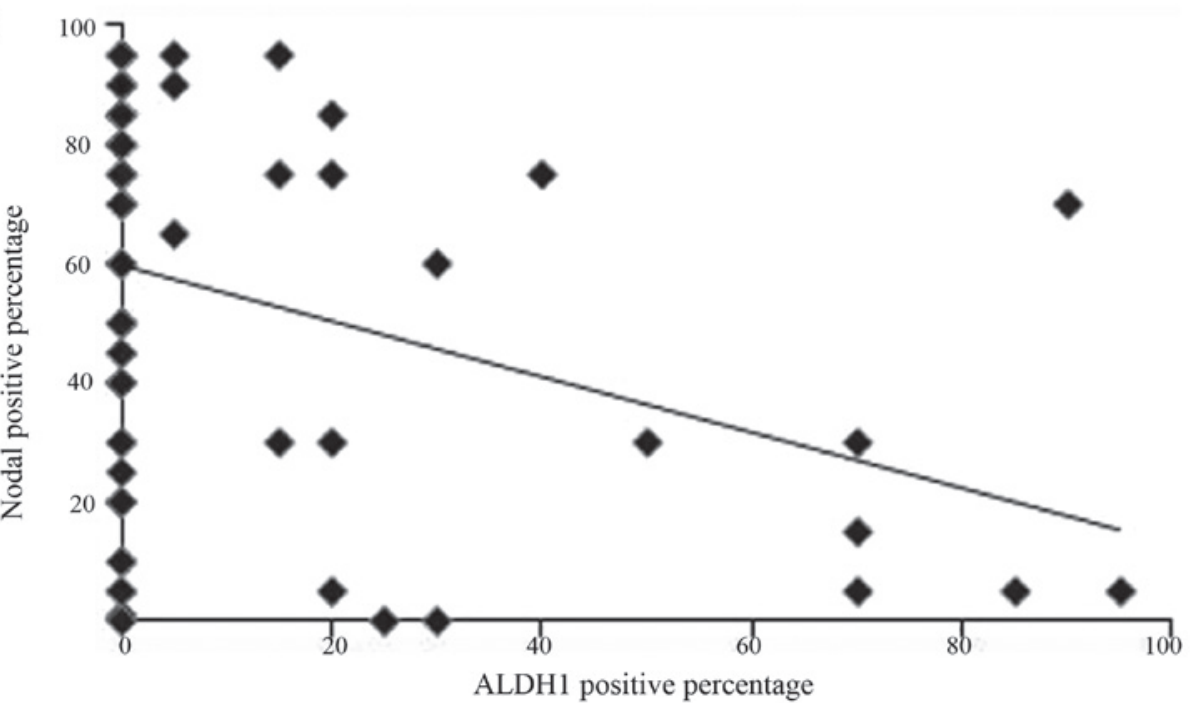

Figure 1. Expression of ALDH1 and Nodal in lung mixed adenocarcinoma. (A) Representative immunohistochemical staining of ALDH1 and Nodal in two representative lung mixed adenocarcinoma tissues. Magnification, x100. (B) Assessment of the association between ALDH1 and Nodal expression (P<0.05; $\mathrm{r}=-0.253$ ) indicated that the expression of ALDH1 and Nodal is inversely correlated. ALDH1, aldehyde dehydrogenase 1.

derived from RNA extracted from A549 cells using a RNeasy Mini kit (Qiagen, Inc.) and reverse transcribed using a Super Script III RNase H-Reverse Transcriptase kit (cat. no. 1244390; Invitrogen; Thermo Fisher Scientific, Inc.), and $1.25 \mu \mathrm{l}$ of specific primer pairs in TaqMan Gene Expression Master mix (cat. no. 1110130; Applied Biosystems; Thermo Fisher Scientific, Inc.) in a $25 \mu \mathrm{l}$ reaction mixture. The human GAPDH primer was purchased from Applied Biosystems (cat. no. 4326317E; Thermo Fisher Scientific, Inc.). The aldehyde dehydrogenase 1A1 (ALDH1A1) primer was also purchased from Applied Biosystems (cat. no. 1164131; Thermo Fisher Scientific, Inc.). Thermocycling conditions were as according to the manufacturer's protocol: 1 cycle at $48^{\circ} \mathrm{C}$ for $30 \mathrm{~min}$, 1 cycle at $95^{\circ} \mathrm{C}$ for $10 \mathrm{~min}$ and 50 cycles each at $95^{\circ} \mathrm{C}$ for $15 \mathrm{sec}$ and $60^{\circ} \mathrm{C}$ for $1 \mathrm{~min}$. Comparative gene expression analysis was performed using normalization to the level of the internal control gene, GAPDH using the $2^{-\triangle \Delta C q}$ method (11).

Statistical analysis. All data are expressed as the mean \pm standard deviation, and statistical analyses were carried out by SPSS 17.0 (SPSS, Inc., Chicago, IL, USA). Statistical analysis was performed using one-way ANOVA and correlations were analyzed using Spearman's rank correlation coefficient. $\mathrm{P}<0.05$ was considered to indicate a statistically significant difference. Experiments data were conducted in triplicate.

\section{Results}

Expression of ALDH and Nodal is negatively correlated in lung mixed adenocarcinomas, and rhNodal downregulated the expression of ALDH on A549 cells. Immunostaining of the expression of ALDH1 and Nodal in lung mixed adenocarcinomas is shown in Fig. 1 and Table I. ALDH1 and Nodal were each expressed in the cytoplasm of the lung cancer cells. For a diagnosis of lung mixed adenocarcinoma, each case must consist of more than one subtype; the percentage of different histology types, and percentage of the positive expression of ALDH1 and Nodal in their respective histology types were evaluated and compared to identify the statistical significance. The results indicated that the expression of ALDH1 and Nodal was inversely correlated (Fig. 1B). In the ALDH1-positive expression area, the expression of Nodal was negative or weak, and vice versa.

Todetect whether the Nodal regulated the enzymatic activity of ALDH, A549 cells were cultured at different concentrations 
Table I. Expression of ALDH1 and Nodal in 28 cases of lung mixed adenocarcinoma.

\begin{tabular}{|c|c|c|c|c|}
\hline $\begin{array}{l}\text { Case } \\
\text { number }\end{array}$ & $\begin{array}{c}\text { Histology } \\
\text { subtypes }\end{array}$ & $\begin{array}{l}\text { Histology } \\
\text { percentage }\end{array}$ & $\begin{array}{c}\text { ALDH1 } \\
\%\end{array}$ & $\begin{array}{c}\text { Nodal, } \\
\%\end{array}$ \\
\hline \multirow[t]{2}{*}{1} & Lepidic & 40 & 70 & 30 \\
\hline & Acinar & 60 & 85 & 5 \\
\hline \multirow[t]{2}{*}{2} & Lepidic & 70 & 0 & 40 \\
\hline & Papillary & 30 & 50 & 30 \\
\hline \multirow[t]{2}{*}{3} & Papillary & 80 & 15 & 30 \\
\hline & Acinar & 20 & 25 & 0 \\
\hline \multirow[t]{4}{*}{4} & Papillary & 10 & 0 & 95 \\
\hline & Micropapillary & 2 & 0 & 95 \\
\hline & Acinar & 8 & 0 & 95 \\
\hline & Solid with mucin & 80 & 0 & 75 \\
\hline \multirow[t]{3}{*}{5} & Papillary & 90 & 90 & 65 \\
\hline & Micropapillary & 5 & 5 & 20 \\
\hline & Solid with mucin & 5 & 5 & 60 \\
\hline \multirow[t]{2}{*}{6} & Lepidic & 70 & 0 & 10 \\
\hline & Papillary & 30 & 0 & 50 \\
\hline \multirow[t]{2}{*}{7} & Lepidic & 20 & 0 & 20 \\
\hline & Papillary & 80 & 0 & 40 \\
\hline \multirow[t]{2}{*}{8} & Lepidic & 90 & 0 & 1 \\
\hline & Acinar & 10 & 0 & 0 \\
\hline \multirow[t]{3}{*}{9} & Lepidic & 70 & 0 & 45 \\
\hline & Papillary & 10 & 30 & 0 \\
\hline & Acinar & 20 & 95 & 5 \\
\hline \multirow[t]{3}{*}{10} & Papillary & 10 & 0 & 5 \\
\hline & Micropapillary & 10 & 0 & 30 \\
\hline & Solid with mucin & 80 & 0 & 20 \\
\hline \multirow[t]{2}{*}{11} & Papillary & 70 & 0 & 85 \\
\hline & Acinar & 30 & 0 & 60 \\
\hline \multirow[t]{3}{*}{12} & Papillary & 70 & 70 & 5 \\
\hline & Micropapillary & 10 & 5 & 95 \\
\hline & Solid with mucin & 20 & 0 & 85 \\
\hline \multirow[t]{3}{*}{13} & Papillary & 40 & 15 & 95 \\
\hline & Micropapillary & 30 & 0 & 95 \\
\hline & Solid with mucin & 30 & 0 & 80 \\
\hline \multirow[t]{3}{*}{14} & Lepidic & 10 & 0 & 30 \\
\hline & Papillary & 45 & 0 & 75 \\
\hline & Acinar & 45 & 0 & 40 \\
\hline \multirow[t]{4}{*}{15} & Lepidic & 10 & 0 & 85 \\
\hline & Papillary & 40 & 0 & 90 \\
\hline & Acinar & 35 & 0 & 95 \\
\hline & Others & 15 & 0 & 0 \\
\hline \multirow[t]{2}{*}{16} & Papillary & 95 & 0 & 70 \\
\hline & Solid with mucin & 5 & 0 & 80 \\
\hline \multirow[t]{2}{*}{17} & Lepidic & 40 & 0 & 90 \\
\hline & Papillary & 60 & 0 & 85 \\
\hline \multirow[t]{2}{*}{18} & Lepidic & 30 & 30 & 60 \\
\hline & Papillary & 70 & 20 & 75 \\
\hline \multirow[t]{2}{*}{19} & Lepidic & 15 & 0 & 75 \\
\hline & Papillary & 85 & 0 & 90 \\
\hline \multirow[t]{3}{*}{20} & Lepidic & 50 & 0 & 70 \\
\hline & Papillary & 20 & 0 & 5 \\
\hline & Micropapillary & 30 & 0 & 25 \\
\hline
\end{tabular}

Table I. Continued.

\begin{tabular}{|c|c|c|c|c|}
\hline $\begin{array}{l}\text { Case } \\
\text { number }\end{array}$ & $\begin{array}{l}\text { Histology } \\
\text { subtypes }\end{array}$ & $\begin{array}{l}\text { Histology } \\
\text { percentage }\end{array}$ & $\begin{array}{c}\text { ALDH } 1, \\
\%\end{array}$ & $\begin{array}{c}\text { Nodal, } \\
\%\end{array}$ \\
\hline \multirow[t]{3}{*}{21} & Lepidic & 60 & 20 & 85 \\
\hline & Papillary & 20 & 90 & 70 \\
\hline & Micropapillary & 20 & 0 & 80 \\
\hline \multirow[t]{2}{*}{22} & Papillary & 90 & 40 & 75 \\
\hline & Micropapillary & 10 & 20 & 30 \\
\hline \multirow[t]{3}{*}{23} & Papillary & 70 & 0 & 45 \\
\hline & Micropapillary & 10 & 0 & 10 \\
\hline & Acinar & 20 & 0 & 70 \\
\hline \multirow[t]{2}{*}{24} & Lepidic & 45 & 70 & 15 \\
\hline & Acinar & 55 & 0 & 50 \\
\hline \multirow[t]{3}{*}{25} & Lepidic & 40 & 15 & 75 \\
\hline & Papillary & 20 & 0 & 80 \\
\hline & Acinar & 40 & 5 & 90 \\
\hline \multirow[t]{4}{*}{26} & Papillary & 10 & 0 & 80 \\
\hline & Micropapillary & 5 & 0 & 85 \\
\hline & Acinar & 10 & 0 & 50 \\
\hline & Solid with mucin & 75 & 0 & 75 \\
\hline \multirow[t]{2}{*}{27} & Acinar & 75 & 70 & 5 \\
\hline & Solid with mucin & 25 & 0 & 85 \\
\hline \multirow[t]{2}{*}{28} & Lepidic & 70 & 0 & 70 \\
\hline & Papillary & 30 & 0 & 80 \\
\hline
\end{tabular}

ALDH, aldehyde dehydrogenase.

$(100,300$ and $500 \mathrm{ng} / \mathrm{ml})$ of rhNodal for $2 \mathrm{~h}$, then the activity of ALDH of the A549 cells was analyzed by flow cytometry (Fig. 2A and B). The result indicated that the activity of ALDH was downregulated by rhNodal.

Activity of ALDH was upregulated by histamine in A549 cells. To determine whether the expression of ALDH is regulated by histamine, subsequent to treatment with histamine at different concentrations and for different durations, the ALDH activity of the A549 cells was detected by flow cytometry (Fig. 3). The results indicated that the activity of ALDH in the A549 cell line could be upregulated by histamine at a concentration of $10 \mu \mathrm{g} / \mathrm{ml}$ and the suitable culturing time span was $2 \mathrm{~h}$. The mRNA level of ALDH1A1 was also detected after treatment with histamine for different durations. The results showed that the mRNA levels of ALDH1A1 of A549 cells increased with the duration of histamine treatment (Fig. 2C).

$H 1 R$ and H2R are expressed in A549 cells. The aforementioned observations prompted the investigation of the histamine receptors present in the A549 cell line. RT-qPCR was used, and the presence and levels of mRNA of histamine receptors were detected (Fig. 4). The results indicated that the subtypes of histamine receptor present in A549 cells are H1R and H2R, but not H3R and H4R.

ALDH activity was regulated by $H 1 R$ and $H 2 R$ agonists and antagonists in A549 cells. Histamine has multiple biological 
$\mathbf{A}$ Control Rhnodal 100 Rhnodal 300 Rhnodal $500 \mathrm{ng} / \mathrm{ml}$
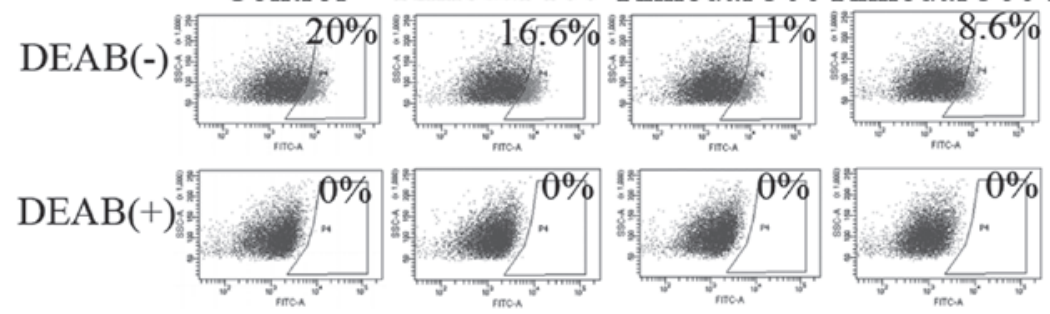

B

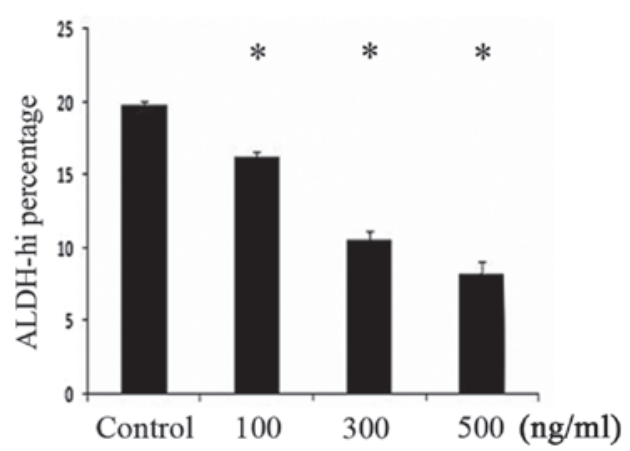

C

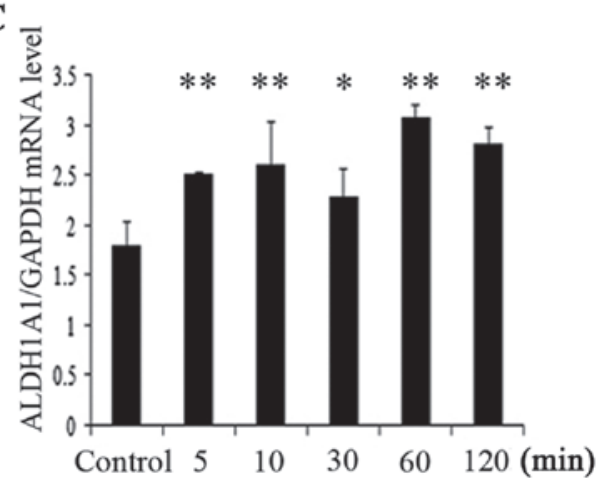

Figure 2. Various concentrations of rhNodal downregulated the activity of ALDH in A549 cells, as determined by flow cytometry. (A) Representative flow cytometry results. The activity of ALDH was inhibited by DEAB; thus, A549 cells were used as a control for background fluorescence subsequent to receiving pretreatment with DEAB $\left(\mathrm{DEAB}^{+}\right)$. (B) Quantitative analysis of the percentage of ALDH-hi cells after treatment with various concentrations of rhNodal (C) Quantitative analysis of the mRNA level of ALDH1A1 in A549 cells after receiving histamine treatment for various durations, as determined by reverse transcription-quantitative polymerase chain reaction. ${ }^{*} \mathrm{P}<0.05,{ }^{* *} \mathrm{P}<0.01$ vs. control; DEAB, diethylaminobenzaldehyde; ALDH-hi cells, ALDH-positive cells.

$\mathbf{A}$
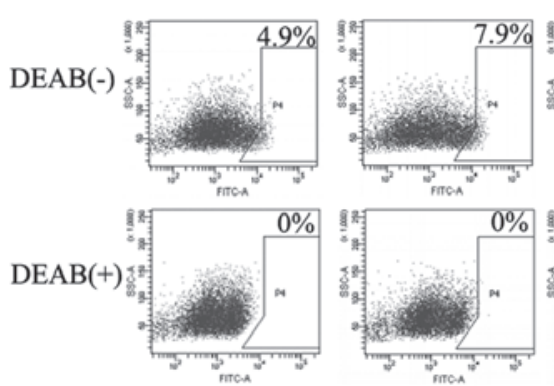

C
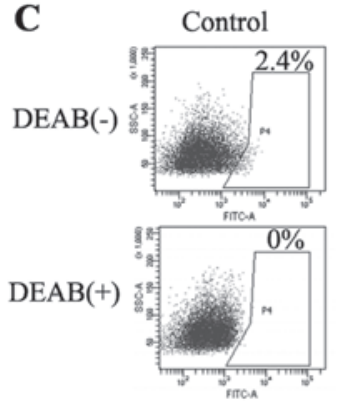

His 10
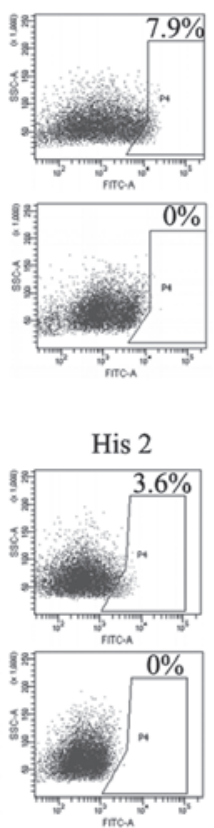

His 100
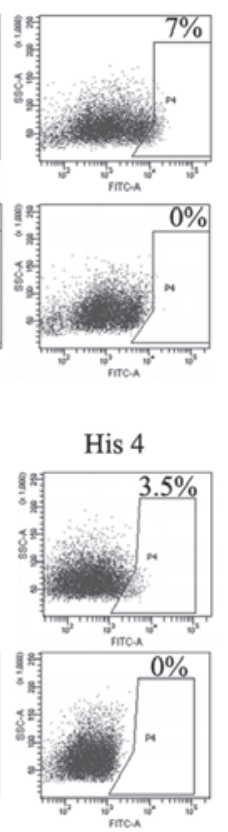

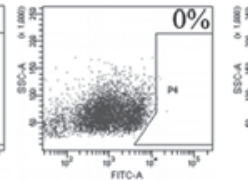

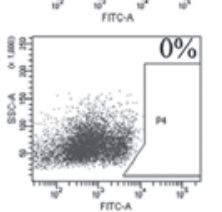

His $500(\mu \mathrm{g} / \mathrm{ml})$
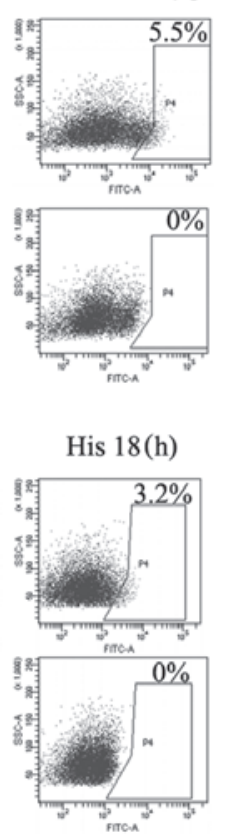

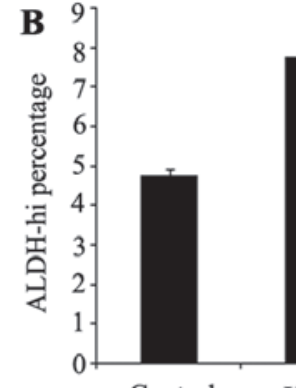

Control
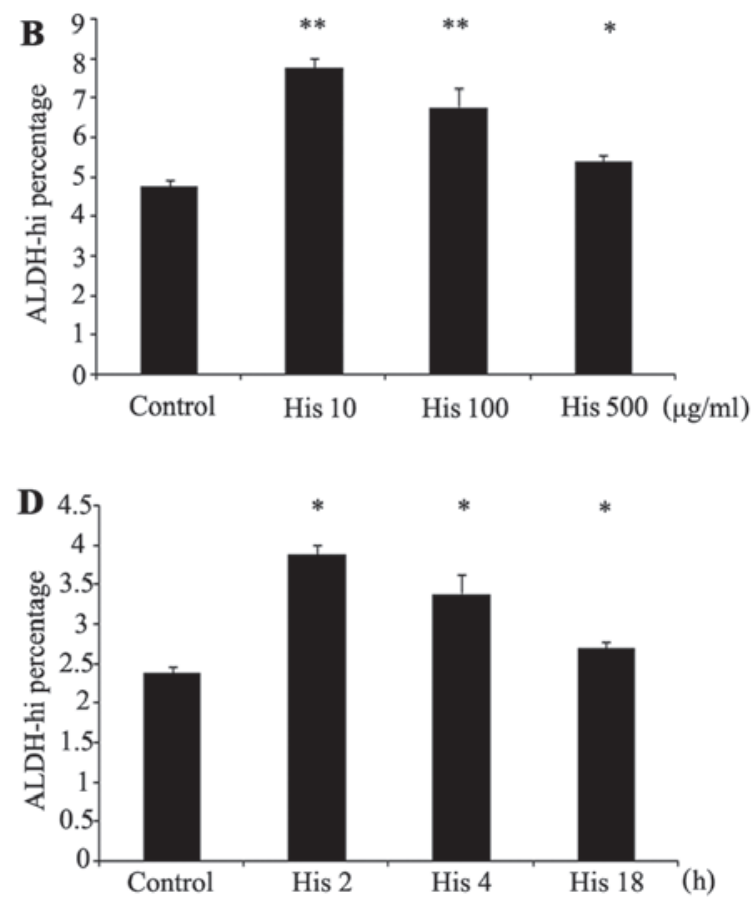

Figure 3. Various concentrations and treatment times of histamine upregulated the activity of ALDH in A549 cells, as determined by flow cytometry. (A) Representative flow cytometry results of A549 cells treated with 10,100 or $500 \mu \mathrm{g} / \mathrm{ml}$ histamine for $2 \mathrm{~h}$. (B) Quantitative analysis of flow cytometry results of A549 cells treated with 10, 100 or $500 \mu \mathrm{g} / \mathrm{ml}$ histamine for $2 \mathrm{~h} .{ }^{*} \mathrm{P}<0.05,{ }^{* *} \mathrm{P}<0.01$ vs. control. (C) Representative flow cytometry results of A549 cells treated for 2,4 or $18 \mathrm{~h}$ with $10 \mu \mathrm{g} / \mathrm{ml}$ histamine. (D) Quantitative analysis of A549 cells treated with $10 \mu \mathrm{g} / \mathrm{ml}$ histamine for $2,4 \mathrm{or} 18 \mathrm{~h}$. ${ }^{*} \mathrm{P}<0.05 \mathrm{vs}$. control. ALDH-hi cells, ALDH-positive cells.

roles and exerts its effects via histamine receptors. Since histamine could upregulate the expression of ALDH in A549 cells, whether the agonists and antagonists of H1R and H2R affect the expression of ALDH was investigated. A549 cells were cultured with agonists and antagonists of H1R, H2R and histamine at different concentrations for $2 \mathrm{~h}$, and the activity of ALDH was detected by flow cytometry. The data showed that ALDH activity was upregulated by H1R and H2R 

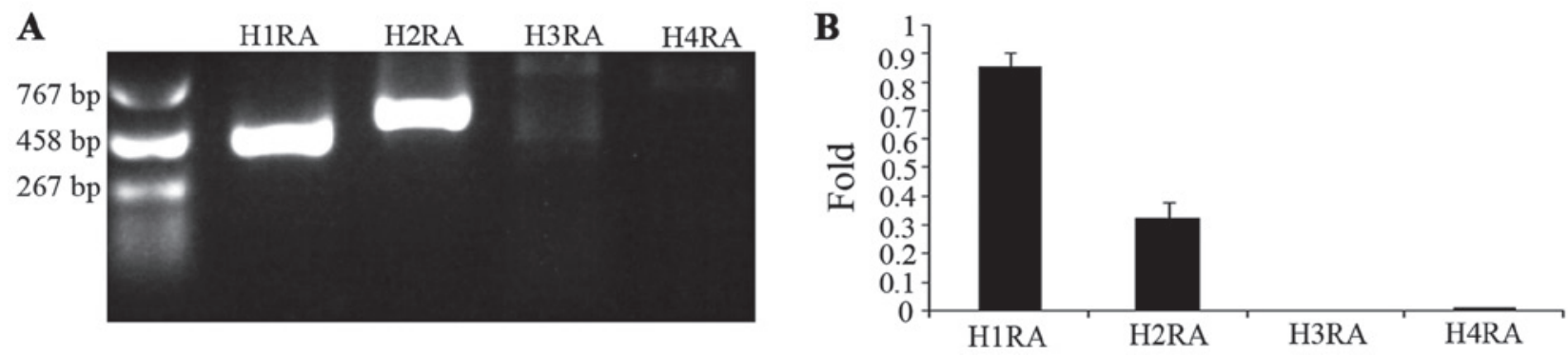

Figure 4. Expression of human histamine receptors in A549 cells. (A) Reverse transcription-polymerase chain reaction analysis of histamine receptor mRNA expression. Lane H1RA, H1R in A549 cells (402 bp); lane H2RA, H2R in A549 cells (495 bp); lane H3RA, H3R in A549 cells; lane H4R, H4R in A549 cells. (B) Ratio of mRNA expression of H1R, H2R, H3R and H4R to the expression of GAPDH. H1R, H1 receptor; H2R, H2 receptor; H3R, H3 receptor; H4R, H4 receptor.

$\mathbf{A}$

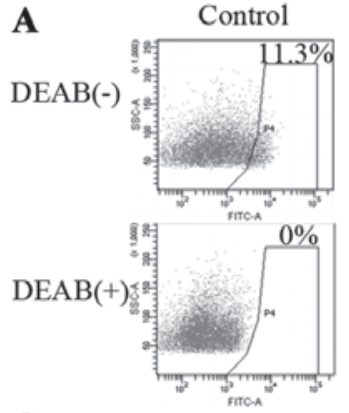

C

Control
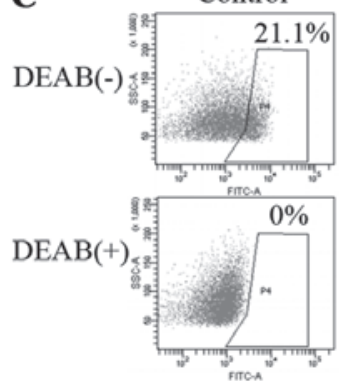
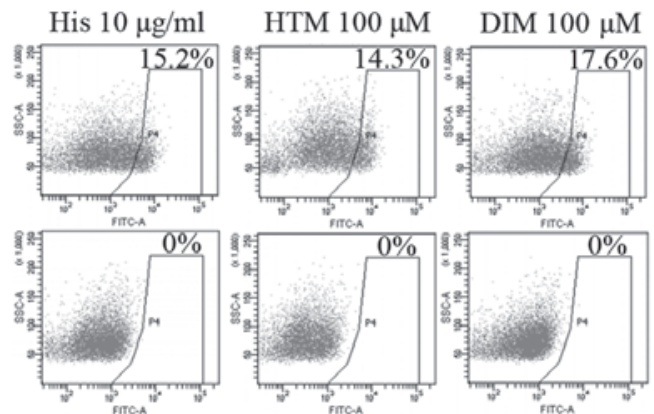

His $10 \mu \mathrm{g} / \mathrm{ml}$
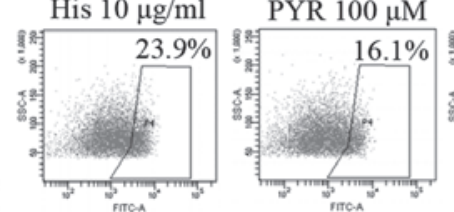

CIM $100 \mu \mathrm{M}$

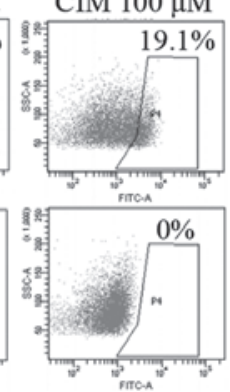

B

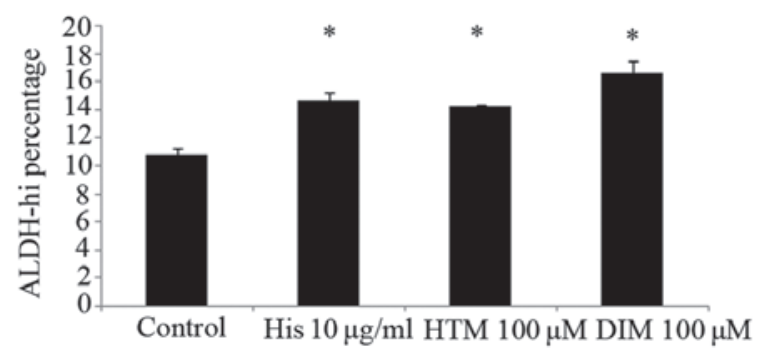

D

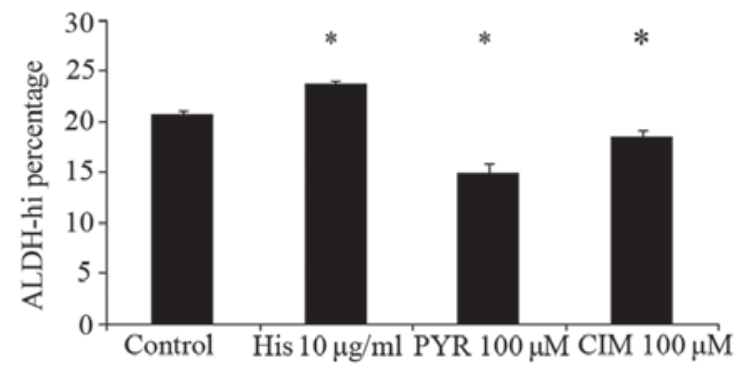

Figure 5. Effect of agonists and antagonists of H1R and H2R on A549 cells for the activity of ALDH. (A) Representative flow cytometry results of A549 cells treated with the agonists of H1R and H2R. Histamine $(10 \mu \mathrm{g} / \mathrm{ml})$ was used as a quantity control. (B) Quantitative analysis of flow cytometry results of A549 cells treated with histamine and agonists of H1R and H2R. ${ }^{*} \mathrm{P}<0.05$ vs. control. (C) Representative flow cytometry results of A549 cells treated with the antagonists of H1R and H2R. (D) Quantitative analysis of flow cytometry results of A549 cells treated with histamine and agonists of H1R and H2R. ${ }^{*} \mathrm{P}<0.05$ vs. control. DEAB, diethylaminobenzaldehyde; ALDH-hi cells, ALDH-positive cells; H1R, H1 receptor; H2R, H2 receptor; HTM, trifluoromethyltoluididedimaleate; DIM, dimapritdihydrochloride; CIM, cimetidine; PYR, pyrilamine maleate salt.

agonists, and ALDH activity was downregulated by H1R and H2R antagonists (Fig. 5).

\section{Discussion}

In the present study, it was confirmed that the expression of ALDH1 is inversely associated with Nodal expression in lung mixed adenocarcinoma, and A549 cells express H1R and H2R, but not the other histamine receptors. The enzymatic activity of ALDH could be upregulated by histamine and agonists of H1R and H2R, as well as downregulated by rhNodal and antagonists of H1R and H2R in the A549 cell line.

Nodal is a member of the transforming growth factor- $\beta$ (TGF- $\beta$ ) family, and it is an important morphogen, performing regulatory function of cell fate in embryological and adult systems (12). It has been reported that TGF- $\beta$ /activin/Nodal signaling may have an effect in maintaining pluripotency in human embryonic stem (ES) cells (13). In addition, Nodal appears to maintain the stemness of stem cells by inhibiting differentiation of neuroectodermal differentiation in the human ES cells (14). Mechanically, the activation of the Nodal receptor may lead to the phosphorylation of Smad2/3. Subsequently, Smad4 and other transcription factors are activated. The activated Smad complexes accumulate in the nucleus, then recognize and bind the Nodal-responsive cis-elements to regulate the expression of their target genes (15). Smad proteins can also form complexes with the other proteins, such as p53, and contribute to the specific recognition and regulation of subsets of Nodal target genes (16). In the present study, Nodal inhibited the expression of ALDH, possibly through a signaling pathway (e.g., TGF- $\beta$ ), which is consistent with a previous study in which ALDH1 was revealed to occur in diffuse-type gastric carcinoma-initiating cells and the expression of ALDH1 and the size of the ALDH1-positive cell population were reduced 
by TGF- $\beta$ (17). In agreement with this, rhNodal was found to reduce ALDH activity in the present study.

Histamine has diverse biological roles and exerts its effects via distinct receptor subtypes, consisting of $\mathrm{H} 1, \mathrm{H} 2, \mathrm{H} 3$ and $\mathrm{H} 4$ receptors. In the majority of human cells, multiple types of histamine receptors coexist. However, H3R is exclusively expressed in neurons (18). Furthermore, it has been reported that no human cell culture model expresses sufficient endogenous levels of H3R to be detected (19). In this previous study (19), the human lung adenocarcinoma A549 cell line was demonstrated to express H1R and H2R mRNA.

Histamine is known to have a notable role in acute and chronic allergic inflammation (20) and also contributes to the proliferation and differentiation of certain cells (21). The binding of histamine receptors and their ligands could trigger serious of reactions, including $\mathrm{Ca}^{2+}$ inflow (22), the activation of phosphatidylinositol (3-5)-trisphosphate signaling pathway (23) and the activation of nuclear factor- $\kappa \mathrm{B}$ $(\mathrm{NF}-\kappa \mathrm{B})$ signaling pathway (24), and they consequently fulfill their various biological functions. It has been reported by Muzio et al (25) that the treatment of A549 cells with arachidonic acid led to a decrease in the enzymatic activity, protein and mRNA levels of ALDH3A1, whereas the expression of proliferator-activated receptor- $\gamma$ increased, and the $\mathrm{NF}-\kappa \mathrm{B}$ binding activity was inhibited. Therefore, the expression of ALDH1 may be indirectly associated with the histamine in A549 cells through a NF- $\mathrm{B}$-associated signaling pathway. In the present study, the activity of ALDH was observed to be slightly enhanced by treatment with histamine, and this process was not only promoted by agonists of H1R and H2R, also suppressed by the antagonists of H1R and H2R.

To conclude, ALDH serves an important function in labeling and protecting CSCs. The exact regulatory mechanism of ALDH expression requires delineation, and therefore further investigation in detail.

\section{References}

1. Parkin DM, Bray F, Ferlay J and Pisani P: Global cancer statistics, 2002. CA Cancer J Clin 55: 74-108, 2005.

2. Egevad L, Heanue M, Berney D, Fleming K and Ferlay J: Histological groups. In: Cancer Incidence in Five Continents. Vol IX. Curado MP, Edwards B, Shin HR, Storm H, Ferlay J, Heanue $\mathrm{M}$ and Boyle P (eds). IARC Scientific Publications, Lyon, pp62-64, 2007.

3. Marcato P, Dean CA, Giacomantonio CA and Lee PW: Aldehyde dehydrogenase: Its role as a cancer stem cell marker comes down to the specific isoform. Cell Cycle 10: 1378-1384, 2011.

4. Al-Hajj M, Wicha MS, Benito-Hernandez A, Morrison SJ and Clarke MF: Prospective identification of tumorigenic breast cancer cells. Pro Natl Acad Sci USA 100: 3983-3988, 2003.

5. Ginestier C, Hur MH, Charafe-Jauffret E, Monville F, Dutcher J, Brown M, Jacquemier J, Viens P, Kleer CG, Liu S, et al: ALDH1 is a marker of normal and malignant human mammary stem cells and a predictor of poor clinical outcome. Cell Stem Cell 1: 555-567, 2007.

6. Marchitti SA, Brocker C, Stagos D and Vasiliou V: Non-P450 aldehyde oxidizing enzymes: The aldehyde dehydrogenase superfamily. Expert Opin Drug Metab Toxicol 4: 697-720, 2008.
7. Black W and Vasiliou V: The aldehyde dehydrogenase gene superfamily resource center. Hum Genomics 4: 136-142, 2009.

8. Travis WD, Brambilla E, Noguchi M, Nicholson AG, Geisinger KR, Yatabe Y, Beer DG, Powell CA, Riely GJ, Van Schil PE, et al: International association for the study of lung cancer/American thoracic society/European respiratory society international multidisciplinary classification of lung adenocarcinoma. J Thorac Oncol 6: 244-285, 2011.

9. Huang EH, Hynes MJ, Zhang T, Ginestier C, Dontu G, Appelman H, Fields JZ, Wicha MS and Boman BM: Aldehyde dehydrogenase 1 is a marker for normal and malignant human colonic stem cell (SC) and tracks SC overpopulation during colon tumorgenesis. Cancer Res 69: 3382-3389, 2009.

10. Fujimoto S, Komine M, Karakawa M, Uratsuji H, Kagami S, Tada Y, Saeki H, Ohtsuki M and Tamaki K: Histamine differentially regulates the production of Th1 and Th2 chemokinesby keratinocytes through histamine $\mathrm{H} 1$ receptor. Cytokine 54: 191-199, 2011.

11. Livak KJ and Schmittgen TD: Analysis of relative gene expression data using real-time quantitative PCR and the 2(-Delta Delta C(T)) method. Methods 25: 402-408, 2001.

12. Strizzi L, Postovit LM, Margaryan NV, Lipavsky A, Gadiot J, Blank C, Seftor RE, Seftor EA and Hendrix MJ: Nodal as a biomarker for melanoma progression and a new therapeutic target for clinical intervention. Expert Rev Dermatol 4: 67-78, 2009.

13. James D, Levine AJ, Besser D and Hemmati-Brivanlou A: TGFbeta/activin/nodal signaling is necessary for the maintenance of pluripotency in human embryonic stem cells. Development 132: $1273-1282,2005$

14. Vallier L, Reynolds D and Pedersen RA: Nodal inhibits differentiation of human embryonic stem cell salong the neuroectodermal default pathway. Dev Biol 275: 403-421, 2004.

15. Massagué J, Seoane J and Wotton D: Smad transcription factors. Genes Dev 19: 2783-2810, 2005.

16. Schier AF: Nodal morphogens. Cold Spring Harb Perspect Biol 1: a003459, 2009.

17. Katsuno Y, Ehata S, Yashiro M, Yanagihara K, Hirakawa K and Miyazono K: Coordinated expression of REG4 and aldehyde dehydrogenase 1 regulating tumourigenic capacity of diffuse-type gastric carcinoma-initiating cells is inhibited by TGF- $\beta$. J Pathol 228: 391-404, 2012.

18. Leurs R, Bakker RA, Timmerman H and de Esch IJ: The histamine $\mathrm{H} 3$ receptor: From gene cloning to $\mathrm{H} 3$ receptor drugs. Nat Rev Drug Discov 4: 107-120, 2005.

19. Seifert R, Strasser A, Schneider EH, Neumann D, Dove S and Buschauer A: Molecular and cellular analysis of human histamine receptor subtypes. Trends Pharmacol Sci 34: 33-58, 2013.

20. Akdis CA and Blaser K: Histamine in the immune regulation of allergic inflammation. J Allergy Clin Immunol 112: 15-22, 2003.

21. Falus A, Pós Z and Darvas Z: Histamine in normal and malignant cell proliferation. Adv Exp Med Biol 709: 109-123, 2010.

22. Hill SJ, Ganellin CR, Timmerman H, Schwartz JC, Shankley NP, Young JM, Schunack W, Levi R and Haas HL: International Union of Pharmacology. XIII. Classification of histamine receptors. Pharmacol Rev 49: 253-278, 1997.

23. Robinson AJ and Dickenson JM: Activation of the p38 and p42/p44 mitogen-activated protein kinase families by the histamine $\mathrm{H}(1)$ receptor in DDT(1)MF-2 cells. Br J Pharmacol 133: 1378-1386, 2001.

24. Bakker RA, Schoonus SB, Smit MJ, Timmerman H and Leurs R: Histamine H(1)-receptor activation of nuclear factor-kappa B: Roles for $\mathrm{G}$ beta gamma- and $\mathrm{G}$ alpha(q/11)-subunits in constitutive and agonist-mediated signaling. Mol Pharmacol 60: 1133-1142, 2001.

25. Muzio G, Trombetta A, Maggiora M, Martinasso G, Vasiliou V, Lassen N and Canuto RA: Arachidonic acid suppresses growth of human lung tumor A549 cellsthrough down-regulation of ALDH3A1 expression. Free Radic Biol Med 40: 1929-1938, 2006. 